\title{
CURRENCY AND FINGERPRINTS: AUTHENTIC REPRODUCTIONS AND POLITICAL COMMUNICATION IN INDONESIA'S "REFORM ERA"
}

\section{Karen Strassler}

When General Suharto stepped down on May 21, 1998, the reaction in the streets was carnivalesque. In Yogyakarta, a center of anti-Suharto demonstrations, sidewalks surged with excited crowds. Taking advantage of the festive mood, an enterprising photographer blew up an image of the fifty thousand rupiah bill that bears Suharto's face. Cutting out the former president, he left a large round hole and charged people to have their picture taken in the former president's place. Other photographers did the same with the Suharto postage stamp and with the official presidential poster that had watched over government offices, workplaces, restaurants, and homes. People lined up to put themselves or their kids in Suharto's newly vacated post. In one case, a photographer placed a placard beneath the poster saying, "Next President of Indonesia." 2 In this moment of opened possibility, it was as if anyone could be president.

\footnotetext{
1 Thanks are due to Nancy Florida, Laura Kunreuther, Rachel Sherman, Ann Laura Stoler, and an anonymous reader for this journal for their insightful comments on earlier drafts.

2 In June 1998, an artist named Yuswantoro Adi did a performance art piece in which he used the fify thousand rupiah bill with a hole in it for people to pose in. The title of the installation was: "Anybody Can Be President" (Siapa Saja Boleh Jadi Presiden). In December 1998, he exhibited a series of paintings at Bentara Budaya, Yogyakarta, with the theme of "money and children." The image of children on the face of bills not only suggests the exploitation of children under capitalism, but also imposes a sign of authenticity (the innocent child) onto a sign of authority lacking moral legitimacy. One painting showed the fifty thousand rupiah bill with the artist's face in Suharto's place with the words underneath, "Not Father
} 
This was "euphoria": an English word (like most of the key words associated with democracy and reform in current Indonesian discourse) that was repeated over and over again in the press. Suharto was replaceable and his image no longer sacred. Back in the spring of 1998, student demonstrators in Yogyakarta calling for the aging dictator's resignation had burned him in effigy - at the time, a dangerous and daring act. The effigy's face was constructed from Suharto's official presidential portrait. Photographs of the burning effigy circulated among students and activists, but no local newspapers dared to publish it. ${ }^{3}$.Then, following Suharto's fall from power, everything changed. Newspapers gleefully showed pictures of these official posters crumpled in garbage heaps. The press printed photographs of student protesters arrested for causing a traffic jam, who appeared in court wearing masks made from photocopies of Suharto's face. When asked by the judge to remove the paper masks, they refused, saying, "We will take off our masks when Suharto, for whom the proof of wrongdoing is already very clear, appears in this court. Meanwhile, although it is not clear what we did wrong, we are the ones brought to court." 4

Here, I examine two kinds of popular political communication that emerged in the so-called euphoric moment of the post-Suharto and pre-Abdurrachman Wahid period: campaign stickers in the form of fifty thousand rupiah bills and statements of support for Megawati Sukarnoputri in the form of blood fingerprints collected on cloth banners. Together, money stickers and blood fingerprints illuminate the dilemmas of Indonesian political communication during an inchoate period in which new opportunities for political expression bumped up against enduring structures of exclusion. I view them as attempts to bridge a gap in communication between political elites and "the people" (rakyat) through popular appropriations of elite signs of power. In money stickers and blood fingerprints, the iconography of the state is reinvented and charged with the task of expressing popular political sentiment. Money stickers and blood fingerprints reveal that in a moment of transition, signs of authenticity are up for grabs and at stake in the struggle to establish new political authority. Oscillating in a double gesture of irreverent mockery and genuine desire for authenticity, these popular forms of political communication provoke a tremor of unease in existing structures of authority.

Development" (Father Development was one of Suharto's chosen titles) and "32 Years Indonesia is Just Awakening" (a play on the Indonesian word for "development," which uses the same word base as the word for "awake"). "Tak Ada Gambar Pak Harto dalam Uang 50 Ribuan," Jawa Pos, December 3, 1998.

3 The managing editor of Yogyakarta's newspaper, Kedaulatan Rakyat, recalls receiving a call from the Department of Information specifically warning him not to run a photo of the burning effigy (personal interview, April 27, 1999, at a seminar on journalistic photography at the Indonesian Islamic University in Yogyakarta). According to an award-winning investigative report in Gadjah Mada University's wellrespected news magazine, an intelligence agent who was captured and interrogated by students had in his wallet the name of the student who made the Suharto effigy burned in the April 4, 1998 demonstration, as well as the names of other students who burned Suharto's photograph. See "Menguak Jaringan Inteligen di Kampus Biru," Balairung, edisi khusus VX 1999, p. 57. Two students, who were mysteriously shot at in Yogyakarta on separate occasions in the spring of 1998 (before Suharto's fall), had been involved in the burning of Suharto's image in the April 4, 1998 action. It is believed that this is one of the reasons they were targeted by intelligence agents. Ibid., pp. 63-4.

4 "'HM Suharto' Dihukum Denda," Kompas, June 22, 1999; see also "Luhut MP Pangaribuan Soal Topeng di Persidangan. Wibawa Peradilan Telah Runtuh," Kompas, June 25, 1999. 
Following Suharto's resignation, the image of the rupiah bill bearing Suharto's benign smile and downcast eyes became an instantly recognizable shorthand that distilled a constellation of discourses on New Order corruption and abuse of power. Discussions were soon underway in the press about who would replace him on the fifty thousand rupiah bill. For the time being, though, the bill with the face of "the smiling general" stayed in circulation. The very fact that the bill was still in use powerfully evoked the widespread belief, throughout late 1998 and well into 2000, that Suharto was still active in the political world-that he still had, in all senses of the word, currency..$^{5}$ The fifty thousand rupiah bill appeared in many cartoons as a visual code for the idea that Suharto's money was behind various scandals and violent eruptions of conflict throughout Indonesia. ${ }^{6}$ During the political campaigns of spring 1999 , there were constant accusations that the New Order ruling party, Golkar, and several smaller parties were playing "money politics," and in these campaigns Suharto's bill figured again as the ultimate sign of political corruption. ${ }^{7}$

Then, several months into the campaign for the parliamentary elections of June 1999, amidst literally hundreds of different party stickers and posters sold on street corners at rallies and in stalls along main commercial streets, a sticker emerged which placed Megawati Sukarno Putri's face on the infamous fifty thousand rupiah bill. As in almost all the political campaign images of Megawati (both mass-produced and handpainted on small streetside "posts" set up by Megawati supporters), she is accompanied by her father: the "watermark" of the bill featured an image of Sukarno. Sukarno, the shadow figure always visible behind her, was the ultimate sign of political authenticity: the "original" Indonesian president and nationalist hero. ${ }^{8}$

Not long after, Mandate Party (PAN, Partai Amanat Nasional) supporters also came out with a fifty thousand rupiah sticker featuring Amien Rais. The scene of Amien Rais's wife handing these bills out to potential voters-mimicking Golkar's wellknown practice of buying votes-elicted playful references to Amien's "simple" wife playing the elite game of "money politics."

5 This despite the fact that following a Time magazine exposé of Suharto's family wealth, Suharto went on television before the Indonesian nation and swore he did not have "a single cent" in foreign banks and that if he had all the money Time claimed he did, he would have been more than happy to give it to the Indonesian people.

6 Throughout 1999 and into 2000 , the fifty thousand rupiah bill appeared on many magazine covers as an illustration for lead articles on corruption and political scandals. See for example Tempo, December 13-18, 1999; Tempo, March 13-19, 2000; Tempo, April 17-23, 2000.

7 A cartoon in Kedaulatan Rakyat, March 6, 1999, shows a variety of party flags, one of which is actually a bill with Suharto's face on it, a sign that parties are being funded with Suharto's money. Another cartoon depicts a party orator who has a sheaf of fifty thousand rupiah bills poking out of his shirt collar instead of a head (reproduced in Bernas, May 27,1999). At a demonstration against "money politics," students in Jakarta dressed up in costumes made entirely of photocopies of the fifty thousand rupiah bill. See Kompas, May 11, 1999.

8 Both Megawati detractors and supporters often claimed that Megawati's political charisma was a direct result of her familial connection to Sukarno. The money stickers establish this familial connection visually. Eventually PDIP money stickers were available in all denominations and a variety of versions. One sticker featured Sukarno rather than Megawati alongside the symbol for PDIP. Another showed Megawati next to her brother, with Sukarno in the background. Others showed Megawati and her father together as the central image of the bill. 
It turns out that the money politics practice that is so much the enemy of the Mandate Party is also done by Ny. Kusnasriyati Sri Rahayu. The wife of the Head of the Mandate Party, Prof. Amien Rais, even gave [money] out from the air while in a helicopter. . . . Don't misunderstand. The money politics done by Amien Rais and his wife is not that of handing out or circulating real money. Rather it is in the form of a sticker which in format and design imitates the fifty thousand rupiah note. The difference is that the amount of the denomination has been changed to fifteen [the official number of the Mandate Party among Indonesia's forty-eight parties], the picture of Suharto has been exchanged with a photo of Amien Rais, and the image is made complete with the Mandate Party symbol on the right side. ${ }^{9}$

Parties like PAN and Megawati's Indonesian Democratic Party of Struggle (PDIP) used their opposition status as capital in these sticker games to define themselves against Golkar with its infamous corrupt practices. ${ }^{10}$ Such antics allowed PAN in particular to join in the campaign fever while cultivating an ironic distance that would appeal to its more intellectual, urban middle-class followers (academics, students, and professionals).

But by far the most widespread were the Megawati money stickers, which seemed to gain in popularity following her party's victory in the national elections. Megawati herself had an urban populist following and cult status that the other candidates lacked; there were always more stickers for Megawati than for any other figure, and posters of Sukarno had long been popular among dissident youth as well as nostalgic elders. ${ }^{11}$ In addition to "inheriting" her father's charisma, Megawati had won a reputation for political authenticity in her own right for her refusal to accept being ousted by Suharto from the leadership of her party in 1996. Megawati also served as a sign of fiscal "cleanliness"; in the popular imagination, Megawati and the Sukarno family were often explicitly opposed to the Suhartos for not having profited off the people. The bills bore slogans such as dilarang korupsi, kolusi, nepotisme ("corruption, collusion, and nepotism forbidden"), and anti-kekerasaan ("against violence"). In place of the authenticating signatures of government officials appeared the as-if-handwritten reformasi keywords jujur ("honest") and adil ("just"). By joining Megawati, Sukarno, and slogans of reform, the money sticker transformed what had become a symbol of corruption back into a legitimate sign, a sign of political and moral authenticity. The money sticker moved simultaneously along planes of idealism and satire, earnestly

9 “'Money Politics' Ala Istri Amien Rais" Kedaulatan Rakyat, May 25, 1999.

10 Though less frequent, there were also National Awakening Party (PKB) fifty thousand rupiah stickers showing the party's leader, Abdurrachman Wahid (Gus Dur), and, in Yogyakarta at least, there were some stickers showing Hamangkebuwono $X$, the Sultan of Yogyakarta, who was also considered a possible presidential candidate. Habibie and other Golkar leaders never appeared on these stickers; they could not have appropriated the symbolics of money and power in the same way as opposition figures could. Had they tried, the interpreted meaning would inevitably have been not that they were replacing Suharto with something new, but rather that they merely stood in his place, and in fact represented "Suharto with a different face" (Habibie appeared in some cartoons as a puppet with Suharto behind him) or a front for the continuation of the "status quo," as it was called in elite political discourse.

11 In 1967 the display of Sukarno's image in public places was banned by the New Order regime. The ban indicates the significance of these visual statements of political allegience. Kedaulatan Rakyat, July 12, 1967. 
summing up popular reformist ideals while reveling in an over-the-top parody of authenticity itself.

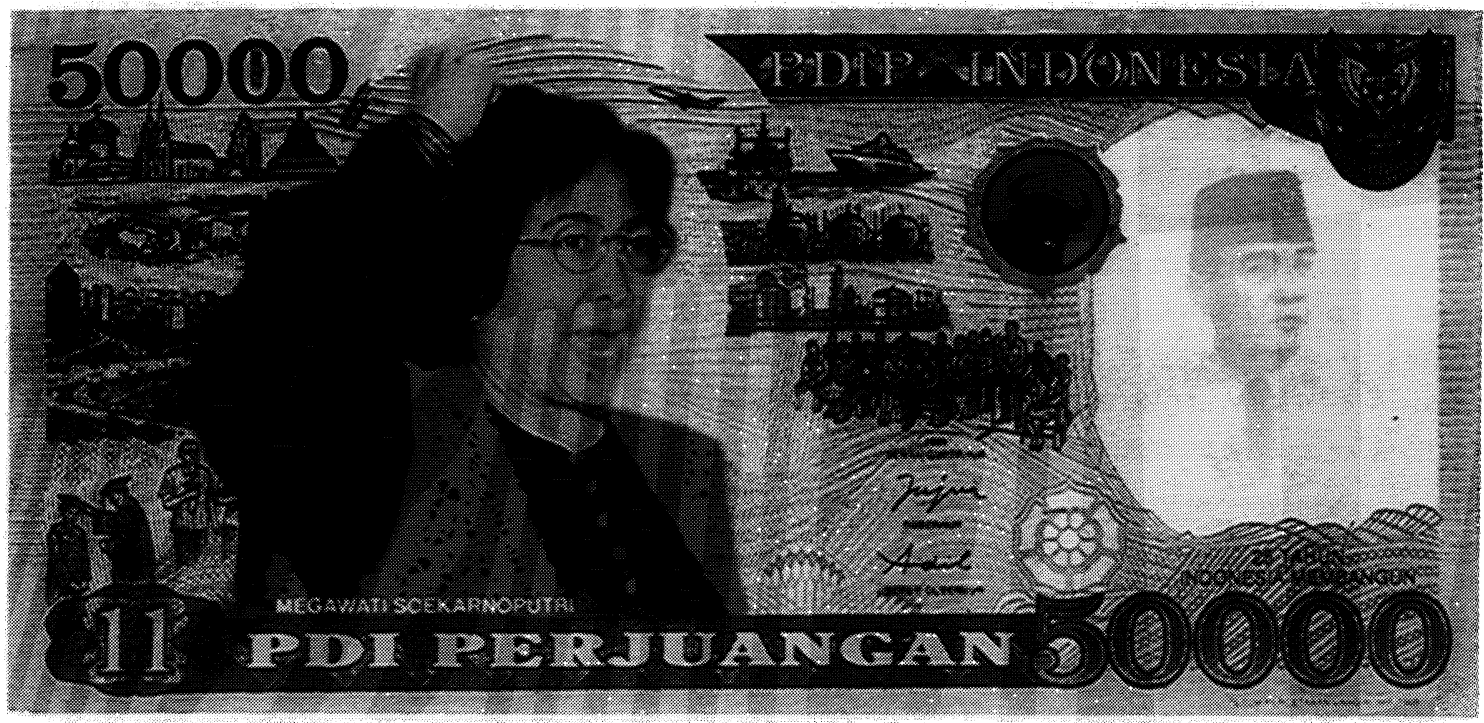

Money sticker

Even if it merely toyed with the idea of replacing the existing currency, the sticker money was subversive. Its circulation raised the radical possibility that the fetish of money should be exposed as mere fiction. In Indonesia, the fictionality of money had particular form: money might be revealed as a piece of paper that expresses not the mystical forces of an impersonal market but a personalized and corrupt form of political power. ${ }^{12}$ In a newspaper article, a PDIP leader, eager to distinguish the party elite from its more radical followers, denied that the stickers were being produced officially by the party:

This sticker could be being made by fanatic supporters of PDI Perjuangan, nevertheless, if it falls into the hands of people, especially those in the villages who are illiterate, it could have saddening consequences. Illiterate villagers who don't know that the fifty thousand rupiah bill with the picture of Mbak Mega is only a game will have problems ... ${ }^{13}$

The voices of the newspaper and the party leader align with the existing order in their tone of paternalistic concern and condescension. Failing to see that non-elites could be capable of irony and humor, they fear that the sticker money might just be taken seriously. The newspaper article reminds its readers that the "authentic" (asli) fifty

\footnotetext{
12 During the economic crisis that hit Indonesia in late 1997 and continues into the present, the severe plummeting of the rupiah against the dollar exposed the corruption corroding the Indonesian economic and financial system. At all levels of society, people felt like victims of forces beyond their control.

13 “Tarik, Stiker Model Uang Bergambar Mega," Kedaulatan Rakyat, May 3, 1999. See also "Stiker Uang Rp. 50,000 Gambar Mega Laris Manis Dijual di Pinggir Jalan," Bernas, July 5, 1999.
} 
thousand rupiah note with the face of Suharto "has also not yet been recalled and is still a legitimate [sah] means of purchasing." Whether stories of villagers mistaking the stickers for real money were elite legends of rural simplicity or actual events is irrelevant. That the stories spread in urban centers like Yogyakarta suggests that the circulation of this "money" was interpreted as a threat to the legitimacy of existing currency.

In fact, the legitimacy of money was already very much in question because of a significant problem with counterfeit money. ${ }^{14}$ During this same time period, there were frequent cases reported in the paper of false bills received from ATM machines and of police raids on counterfeiters. Both the army and Golkar were, at different points, implicated in the production of false money. During the pre-election campaigns, there were rumors that Golkar was handing out envelopes containing fake bills to their would-be supporters, thereby cheating both the democratic system and those who would be bribed. Interestingly, the press reported that the rupiah note most commonly counterfeited was that with Suharto's face on it, thus undermining public confidence not only in money in general, but in that bill in particular. ${ }^{15}$

The Megawati money stickers reverse the logic of the "aspal," a neologism that combines the words "asli" (authentic) and "palsu" (false)-an authentic counterfeit. An example of aspal, as James Siegel has noted, might be an official letter that was acquired through bribery or some kind of scheme, but which cannot be distinguished from an authentic letter because it bears the real stamp: it is the work of someone "on the inside." 16 The money sticker, by contrast, is visibly false and makes no pretense of having been printed officially; but it lays claim to a kind of political authenticity precisely for that reason. Printed far from the centers of financial and political control, this fake money pokes fun at money's authenticating signs and, at the same time, imagines what authentic currency might look like.

Nor is the money sticker like counterfeit money, which ideally slips unnoticed into circulation. For it is, of course, a sticker, meant to be fixed in one place-and thus it violates one of the foundational principles of currency. Indeed, the sticker expressed a contradictory relationship to capitalism and the logic of money. On the one hand, the money sticker could only operate successfully because it was recognized as a sign of value and power. Purchased for one thousand to fifteen hundred rupiah (approximately fifteen to twenty cents), the sticker was itself a commodity. But what the stickers amounted to, in a sense, was a refusal of capitalism, for they enabled people to take money out of circulation, to hold it in abeyance, to possess it rather than have it possess them. The "value" of this money did not result from exchange, but from its use as a symbol of political alternatives and possibilities. The money sticker

14 For a series of articles on the problem of counterfeit money, see Forum April 16, 2000, pp. $12-24$.

15 See "Awas 'Suharto' Palsu di Mana-Mana," Forum, April 16, 2000, pp. 12-13, and "Gunung Es Bergambar Suharto," Forum April 16, 2000, p. 22. The articles also note that the most dramatic rise in counterfeit bills occurred in May 1998 during the transition from Suharto to Habibie and the ensuing rush on banks by panicked citizens.

16 James T. Siegel, A New Criminal Type in Jakarta (Durham: Duke University Press, 1998), see Chapter Three. Bank Indonesia was also accused of circulating this kind of "aspal" money. See "Gunung Es Bergambar Suharto," Forum, April 16, 2000, p. 20. 
thus represented money's antithesis even as it gained its semiotic currency from the logic of money.

One might say that these flagrant forgeries fulfilled what Benjamin called the revolutionary potential of mechanical reproduction. ${ }^{17}$ Benjamin noted that mechanical reproduction enables people to "get hold of" reality and bring it closer; here, the reproduced image allows people symbolically to grasp realms of money and power that are structurally beyond their reach. ${ }^{18}$ That the fake money sticker proved more popular than any other political sticker-showing up on cars, buses, becak (pedicabs), peddlers' stands, and in people's homes on doors, windows, and mirrors-suggests that these images captured better than any other political imagery the "aspirations of the people" (aspirasi rakyat). ${ }^{19}$ Not only did the stickers symbolically allow people to exert control over the distant forces of the economy, but they made an abundance of money physically part of the landscape of the urban lower class. ${ }^{20}$ Attached to the spaces of small-scale commerce and domestic life, the stickers made an abundance of money physically part of the everyday landscape of the urban lower class. At the same time, the stickers brought Megawati into intimate proximity, enacting the popular sentiment that Megawati was a leader who merakyat, who was "one with the people." 21 Her face on the money sticker was not just an abstract sign of authority; it was, in some sense, a reflection of their own. The stickers thus allowed people to imagine a new, more direct and connected, relationship to the economy and to politics.

The money stickers approach the revolutionary potential of mechanical reproduction by undermining the authority of existing currency and expressing a popular revision of politics and money. Yet in their fixation on Megawati's image, the stickers rely on the "cult value" of the portrait photograph, the last holdout of the "aura" of original presence that, for Benjamin, truly revolutionary mechanical reproduction was destined to destroy. ${ }^{22}$ They reinvigorate rather than eliminate the "aura" of authenticity, and so embody, too, the dangerous potential for fascistic politics in the age of mechanical reproduction. For those (mostly middle class and well-educated) Indonesians who found Megawati's following too "fanatik," the money

17 Walter Benjamin, "The Work of Art in the Age of Mechanical Reproduction," in Illuminations, ed. Hannah Arendt, trans. Howard Zohn (New York: Schocken Books, 1968). Money is, of course, an odd example of the auratic object in that it is not an original in the sense of being a unique object located in a particular place and time. On the other hand, money bears the aura of authenticity through its singular origin in the state, its defining, authenticating physical properties (paper quality, water mark, metal strips, etc.), and the fact that it cannot be legitimately reproduced.

18 Benjamin, "The Work of Art in the Age of Mechanical Reproduction," p. 223.

19 The term "mewakili aspirasi rakyat" (representing the aspirations of the people), was the catchword of the election-the single phrase that was meant to sum up the meaning of democracy.

${ }^{20}$ Many of Megawati's supporters in the urban lower class would rarely have held an actual fifty thousand rupiah bill. A becak driver in Yogyakarta may make as much as ten thousand rupiah a day. Skilled laborers (carpenters, for example) often make as little as seven thousand rupiah a day.

21 Obviously this discourse of Megawati's identification with "the people" echoes Sukarnoist rhetoric. As one Megawati supporter, a woman in her mid-fifties, told me, "Megawati has the spirit of her father, the spirit of being one with the people." (Megawati punya jiwa bapaknya, jiwa merakyat).

22 Benjamin, "The Work of Art in the Age of Mechanical Reproduction," p. 226. See also Walter Benjamin, "A Short History of Photography," in Classic Essays on Photography, ed. Alan Trachtenberg (New Haven: Leete's Island Books, 1980), pp. 199-216. 
sticker was further evidence of Megawati's dangerous status as a populist icon. Rather than opening the giddy possibility of putting anybody in Suharto's place-as did the souvenir photos immediately following Suharto's fall-the money stickers provided a replacement. Irreverence and open possibilities had given way to a new form of worship.

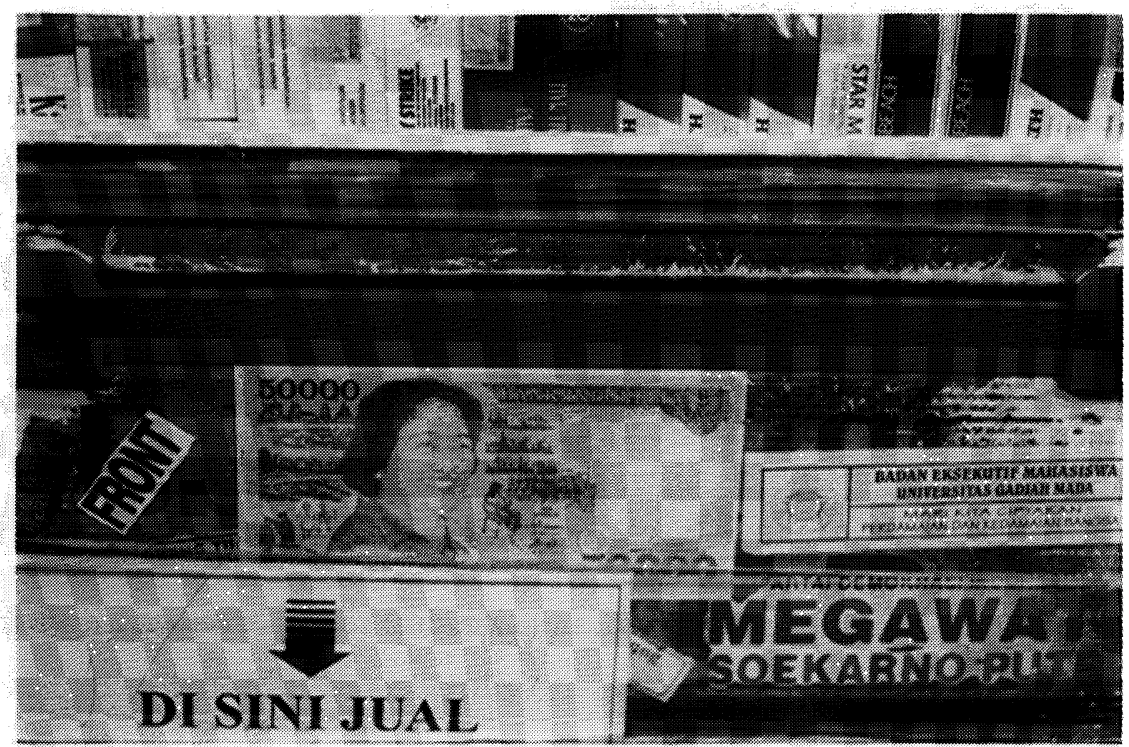

Cigarette seller's box, Yogyakarta, May 1999. (A pack of cigarettes costs about 2,500 Rp.)

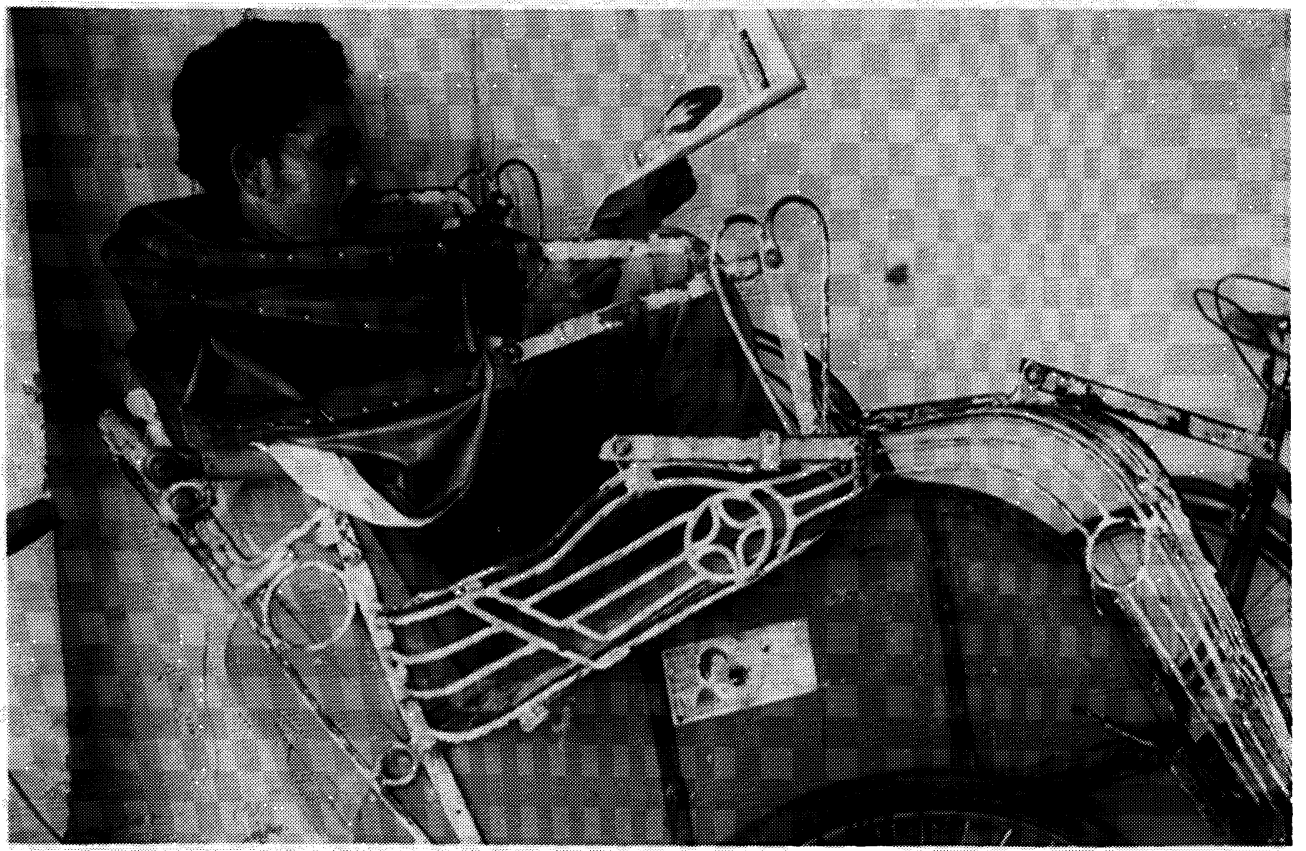

Becak driver reads the paper while waiting for a passenger, Yogyakarta, March 2000. 
If reimagining money was one way that Megawati supporters expressed their desire to engage in the political process, a different but related way to articulate political aspirations emerged after Megawati won the majority vote in the June 1999 general election. Due to the fact that the Indonesian electoral system selects a president by parliamentary vote, winning a majority of the popular vote does not guarantee winning the presidential seat. Groups within Parliament quickly began forming alliances to defeat Megawati's bid for rule. To many of Megawati's supporters this seemed patently unjust, a betrayal of the people's will manifested in the election results. Groups of mostly young men began taking an "oath" to fight for her victory which culminated in pricking one's thumb and making a thumbprint in blood on a white sheet that would be displayed and then sent to Parliament. Other less "fanatik" and less gendered gestures of support included public signings of long white cloth banners by thousands of people in support of Megawati's candidacy for president. ${ }^{23}$ These handsigned banners were a form of graffiti infringing on a medium (the street banner or spanduk) long monopolized by the government and official parties. Just as the money stickers symbolically put money and power in the hands of the wong cilik ("little people") who formed the base of Megawati's support, the cap jempol darah ("blood fingerprint") and the tandatangan ("signature," literally, "hand mark") appropriated the state's own indexical signs for identification in order to express her supporters' desire to make a mark on the political process.

As with the money sticker, party leaders denied that the action was orchestrated by the party, calling it instead a "pure" (murni) act by "citizens" (warga) sympathetic to Megawati. ${ }^{24}$ In media coverage of the participants in the blood fingerprint actions, the threatening term "masses" or "mob" (massa) appears infrequently and is not used self-referentially; rather, it tends to be used by critical elite commentators or editorially by the newspaper itself. Supporters of and participants in the action tend to use more neutral and positive terms, such as masyarakat ("people" or "the public") and rakyat ("the people"). Perhaps most common, tellingly, was the term warga, which when used alone means "citizens" and when used in conjunction with other terms can mean "member of," as in warga PDIP ("PDIP followers") or warga masyarakat ("members of society"). By using the term warga, the supporters of the action asserted their legitimate rights as members of a political and social community, and refused the lawless and politically radical connotations of massa.

In the press, the blood fingerprint was depicted as a form of direct communication from the people to their leaders, rooted in "emotion" rather than "rationality." Horrified elite commentators referred to the blood thumbprint as a form of "political terror." 25 Said one professor of political science, "This is very regrettable. It should be that problems having to do with the election and democracy are regarded rationally,

23 Though less popular, there were also some cap bibir, or lip print sheets, a feminized version of the blood thumbprint.

24 See "Cap Jempol Darah, Bukan PDI-P," Kedaulatan Rakyat, July 1, 1999 and "Cap Darah Dilawan Jihad," Bernas, July 6, 1999.

25 “Cap Darah Juga Menetes di Semarang," Bernas, July 1, 1999. 
not with emotion." 26 In an article titled, "The Blood Thumbprint, Proof of the Return of Mythic Culture," another elite intellectual characterized the blood fingerprint as a survival from an era of blood sacrifice and a sign that Indonesian people are "extremely far from the modern culture of the industrial era." 27 Dr. Djoko Saryono of IKIP (Institut Keguruan dan Ilmu Pendidikan) Malang is quoted in the article as saying, "it makes perfect sense that it will be difficult to eliminate corruption, collusion, and nepotism, because a mythical culture does not know rational terminology like efficiency, property rights, and black-on-white proof." The article quotes further: "concepts of nationalism, statism, democracy, the free market, which are purely modern concepts, obviously are very difficult to be understood by a mythical society."

Interestingly, Dr. Djoko Saryono opposes the blood thumbprint to the "black on white proof" essential to modern polities. He also describes this "mythical culture" as an "oral culture," identifying the blood fingerprints with a pre-literate society in which, he imagines, "blood sacrifice" was practiced to propitiate the spirits of "nature." Yet if blood evokes such elite fantasies of primitivity, completely ignored is the fact that these signs refer to one of the major rituals of modern biopower and bureaucracy. The fingerprint as a sign of identification, a proxy for the individual subject, is of course one of the most utterly "modern" of signs. The modern rite of fingerprinting (required for many official documents in Indonesia) has been a principal site of encounter between the state apparatus and the rakyat in Indonesia. ${ }^{28}$ It is participation in such state rituals-like the ritual of voting - that transforms individuals into warga.

Those who supported the blood fingerprint actions also emphasized the emotional connotation of blood, but gave it a positive cast. The blood print was seen as an authentic and direct "from the heart" form of communication, a "spontaneous" and "pure" outpouring of support. ${ }^{29}$ The fingerprint was called by one sympathetic journalist a "sincere effort in the search for a feeling of justice which during the New Order they [the people] never felt." 30 It was interpreted as the people's response to the intricate, Machiavellian calculations of the party politicians who would ultimately determine who sat in the president's chair. In an article entitled, "PAN Supporters of East Java Do the Blood Fingerprint. The Silent Resistance Spreads," the blood fingerprint is seen as a mute but effective form of communication by those who have been silenced: "It turns out this blood fingerprint action is capable of answering the maneuvers of the political elite who want to get in the way of Indonesian Democratic

\footnotetext{
26 "Cap Jempol Darah Menggila," Kedaulatan Rakyat, June 30, 1999.

27 "Cap Jempol Darah, Bukti Kembalinya Kebudayaan Mitis," Kompas, July 17, 1999.

28 All Indonesian citizens above the age of seventeen must possess a Kartu Tanda Penduduk, a citizenship identification card. Identity is proved through a photograph and a signature and/or a fingerprint. In some contexts, the use of the fingerprint may be a mark of illiteracy. Here what might be a sign of shame is transformed into an authentic form of political communication.

29 See for example, "Cap Jempol Darah Rambah Magelang," Bernas, July 7, 1999, where a local party official claims that this is "a pure, spontaneous action" (kegiatan itu murni spontanitas warga).

30 "Cap Darah Juga Menetes di Semarang," Bernas, July 1, 1999.
} 
Party for Struggle leader Megawati's steps towards the presidential chair," said one party leader. ${ }^{31}$

But alongside this language of emotion and resistance, the blood fingerprint was also frequently referred to by its supporters and practitioners as a form of "proof"-a reference to the legal apparatus to which the fingerprint is inevitably linked: "We are going to bring the proof [bukti] of these blood fingerprints to Senayan [Jakarta], and will give it to the institution or to whomever has authority in the matter of Megawati's candidacy for president," said one organizer of a fingerprint action in East Java. ${ }^{32}$ Filling a spanduk with signatures rather than blood fingerprints, an action far less threatening to elites, was also seen as a form of communication authentic to the people yet framed in a language authority could hear: "At the very least, we will hang it along the road in front of the parliament building. So the members of parliament know the true feelings of the people," said a Megawati supporter. ${ }^{33}$ Another signer of the spanduk, a young woman, is quoted saying, "I only wish the facts of the field to speak." 34

What is clear in these efforts is the sense of a break in communication between political elites and "the people" that emerged following the general election, when it became apparent that, despite her victory, Megawati might not win the presidency. Particularly for those in the urban lower class who formed Megawati's most ardent supporters, who had just been inundated with public service messages about voting and having their voices heard, there was a sense that this newly found voice was being taken away. In response, the signature and the fingerprint-authorized, indexical signs of identity-became alternative means of communication. Is it any surprise, given the urgency of these signals, that when Megawati failed to become president her supporters in several cities rioted? In Bali, they burned government buildings. In Solo, in addition to burning government complexes, the home of Amien Rais, who was seen as the key player in Megawati's defeat, was trashed by her supporters. Violence was narrowly averted in Jakarta by Megawati's televised and radio broadcast plea to her supporters to accept Wahid's victory, and by the immediate appearance of several key political figures, including Amien Rais, to address the disappointed masses gathered in the streets. Megawati's selection as vice president may have been the only way to avert mass violence. Is violence then the result of failed communication, or a last ditch attempt to be heard?

Money stickers and blood fingerprints are bound up in the play of authenticity and reproduction that seems to motor political communication in the reformasi era. Communication between "power" and "the people" cannot take place directly; it occurs by way of reproductions or proxies invested with codes of authenticity. The money sticker relies on reproductive technology to expose the pretensions of conventional signs of authority and to reimagine money as an authentic sign. The

31 "Warga PAN Jatim Ikut Lakukan Cap Jempol Darah. Perlawanan Diam Kini Meluas," Kedaulatan Rakyat, July 5, 1999. Note that although PAN elites were instrumental in Megawati's defeat, at least some PAN supporters chose to align themselves with the popular sentiment that Megawati deserved to win.

32 “Cap Jempol Darah Menggila," Kedaulatan Rakyat, June 30, 1999. See also "'Cap Jempol' Berubah 'Perang Darah," Kedaulatan Rakyat, July 4, 1999.

33 "'John Lennon' pun Mendukung Megawati," Kompas, July 12, 1999.

34 "Cap Darah Juga Menetes di Semarang," Bernas, July 1, 1999. 
popular circulation of this unauthorized money as part of the political campaign is a mimicry and an ironic critique of the unauthorized use of money for political gain-and of political authority for financial gain-practiced by Suharto and his cronies. Any reproduction of money threatens to unravel the fetishistic power of money as a neutral medium representing market forces rather than human agency. But counterfeit money is merely false, whereas the sticker is false but true, a reproduction that is (perhaps) more authentic than the real thing. Like the money sticker, the cap jempol darah invests a reproduction with codes of authenticity. The fingerprint is a proxy for the individual subject within the language of signs recognized by the modern bureaucratic state. The vote has proved an inadequate form of "voice," so individuals who have been silenced seek to communicate by appropriating the language of bureaucratic rationalism, legal proof, and state control. But the use of blood rather than ink deepens the indexicality of the sign and conveys identity overlaid with the suggestion of violence and emotion.

If money stickers tapped popular sentiments of irreverence and hopeful anticipation, the blood fingerprints registered increasing frustration as the political drama of the elections unfolded. While the money stickers reproduced money in order to pull it out of circulation and bring it closer to the people, the fingerprint-filled spanduk attempted to put the people into circulation, to represent them in an exchange of political signs from which they had been unexpectedly excluded. Both money stickers and blood fingerprints were attempts at communicating popular sentiments via authentic reproductions; both were messages that never quite arrived in the elite centers to which they were addressed. 